\title{
Jodoh dan Perjodohan Santri Jamaah Tabligh di Pesantren Temboro
}

\author{
M. Yusuf Khummaini* \& Sukron Ma'mun** \\ Fakultas Syariah IAIN Salatiga \\ Email: yusufkhummaini@gmail.com
}

\begin{abstract}
This article studies a sociological pesantren community, particularly a relationship between male and female students in Jamaah Tabligh in Pesantren Temboro. Relationship pattern of male and female students in a pesantren (a traditional Islamic education based on boarding school) tends to be exclusive that inhibits both male and female students to have relationship closely. Interestingly, many students get married at the end of their study. This study investigates how the process on selecting mate, both male and female students, what is the concept of selecting mate (partner) on their perspective, and how the marriage process is practiced by students of Pesantren Temboro. More important is how woman rights on choosing a mate that is determined by their parents. This study is limited field research in Pesantren Temboro, Magetan, East Java as recognized as the largest Islamic education of Jamaah Tabligh in Indonesia. Researchers got the data by interviewing pesantren functionaries related and santri families that did marriage in the pesantren.
\end{abstract}

Keywords: Mate, Arranged marriage, Woman Rights, Jamaah Tabligh.

${ }^{*}$ Dosen Fakultas Syariah Institut Agama Islam Negeri (IAIN) Salatiga.

** Dosen Fakultas Syariah Institut Agama Islam Negeri (IAIN) Salatiga. 


\begin{abstract}
Abstrak
Kajian ini berangkat dari persoalan sosiologis masyarakat pesantren, yakni pola relationship santri khususnya dalam hubungan laki-laki dan perempuan di pesantren Jamaah Tabligh, Temboro. Pola hubungan santri Temboro putra dan putri cenderung tertutup yang tidak memungkinkan keduanya untuk "hubungan khusus" untuk mengenal satu dengan yang lainnya. Namun hal yang menarik adalah banyak terjadi pernikahan yang terjadi antara santri putra dan putri di Pesantren Temboro ini. Di sinilah letak menariknya kajian ini, yakni menelusuri bagaimana proses pemilihan jodoh, baik santri putra ataupun santri putri. Bagiamana konsep pemilihan jodoh tersebut? Serta bagaimana praktik pernikahan tersebut dilakukan oleh santri? Hal yang tidak kalah penting adalah bagaimana "hak pilih" perempuan dalam penentuan jodoh yang dilakukan oleh wali? kajian ini merupakan studi lapangan yang terbatas di Pesantren Temboro Magetan Jawa Timur yang terkenal sebagai pendidikan Jamaah Tabligh Terbesar di Indonesia. Peneliti mengumpulkan data melalui wawancara pada pengurus pesantren yang terlibat dalam proses perjodohan dan para santri yang telah menikah dengan melalui proses tersebut.
\end{abstract}

Kata Kunci: Jodoh, Perjodohan, Hak Perempuan, Jamaah Tabligh.

\title{
Pendahuluan
}

esantren Temboro, merupakan pesantren salaf
(tradisional) sebagaimana pesantren salaf lainnya dalam
kurikulum dan pendidikan. Namun demikian ada beberapa perbedaan yang menarik yang membedakan dengan pesantren salaf pada umumnya ${ }^{1}$. Titik perbedaan tersebut

${ }^{1}$ Dalam hal ini dapat dilihat pengajaran di Pesantren Temboro masih didominasi kitab-kitab kuning sebagaimana dikaji pada pesantren tradisional nahdliyyin lainnya. Lihat Zamakhsari Dhofier, Tradisi Pesantren: Studi Pandangan Hidup Kyai, (Jakarta: LP3ES, 1999). dan Al-Kutub Al-Muqorroroh 
adalah adanya kurikulum yang menjadi ciri khusus, sistem pendidikan santri khusus dalam bidang dakwah, dan bangunan tradisi pesantren yang unik.

Pesantren Temboro nampaknya telah memiliki corak tersendiri semenjak akhir tahun 1980an setelah datangnya rombongan Jamaah Tabligh dari Pakistan. Bahkan Pesantren Temboro kini merupakan pusat pendidikan Jamaah Tabligh terbesar di Indonesia. ${ }^{2}$ Persinggungan dengan Jamaah Tabligh dan kemudian diadopsinya sistem dakwahnya menjadikan Pesantren Temboro memiliki kurikulum dan tradisi yang berbeda. Tradisi Timur Tengah dan Muslim India banyak diadopsi oleh komunitas santri Pesantren Temboro mengingat, dengan konsepsi kembali ke Sunnah Rasulullah. Kembali ke Sunnah ini artinya bukan hanya nilai-nilai ajaran saja yang harus dikembalikan tetapi juga tradisi dalam artian fisik dan non fisik berlaku .

Demikian pula dalam persoalan tradisi yang lainnya, termasuk dalam persoalan perjodohan dan pernikahan. Model ta'aruf santri putra dan santri putri, khitbah, hingga proses pernikahan mempertahankan ajaran Islam sebagaimana tradisi Rasulullah dan sahabat-sahabatnya. Dengan demikian Pesantren Temboro mempertahankan ke-salaf-an (tradisionalis)

Program Pondok Pesantren Al-Fatah, Temboro, Karas Magetan, Jawa Timur, 2016.

${ }^{2}$ Farish A. Noor, The Spread of the Tablighi Jama'at Across Western, Central, and Eastern Java and the Role of India Muslim Diaspora (RSIS Working Paper, No. 175), (Singapore: Nanyang Technological University, 2009), 39-43.

${ }^{3}$ Jan A Ali menyebut Jamaah Tabligh sebagai kelompok tradisional yang mampu bertahan dalam modernitas. Lihat Jan A. Ali, "Tabligh Jama' at: A Transnational Movement of Islamic Faith Regeneration", Jurnal Ejeps, Vol. 2, tahun 2010. Lihat pula Abdul Aziz, "The Jamaah Tabligh Movement in Indonesia: Peaceful Fundamentalist", Jurnal Studia Islamika, Vol.11, No. 3 tahun 2004, 467-517 dan Sukron Ma'mun, Arabic-Islamic Culture of Tablighi Jamaat: A Case Study in Hyderabad, Indian (penelitian), Hyderabad, EFLU Hyderabad, India, 2013. 
yang berbeda dengan tradisionalis pesantren lainnya yang cenderung akomodatif terhadap budaya lokal masyarakat Jawa.

Di sinilah titik menarik dari kajian ini secara umum. Namun hal yang ingin dibahas dalam kajian ini adalah tradisi santri yang terkait dengan perjodohan dan pernikahan yang berlangsung di kalangan santri Temboro. Pemilihan jodoh, perhatian pada kafaah atau kesederajatan calon pasangan, pertunangan (khitbah), dan prosesi aqad nikah menjadi sesuatu yang menarik untuk dicermati. Tradisi pernikahan dan hal-hal yang terkait tentunya tidak begitu saja dilakukan tanpa dasar pertimbangan, namun semua didasarkan sunnah Rasulullah, sebagaimana ajaran atau norma agama yang mereka pahami dalam proses pembelajaran di pesantren tersebut.

Kharisma kyai dan pengaruh tradisi Arab juga memiliki pengaruh pembentukan kesadaran keagamaan yang dimiliki oleh santri atau orang-orang yang berada dalam kepatuhan terhadap sosok kyai. Hal ini dimungkinkan karena Kyai memiliki hubungan bukan hanya sebatas ikatan intelektualitas, tetapi juga ikatan batin seperti hubungan bapak dengan anaknya (patronase). Santri-santri memiliki kepatuhan terhadap pilihan kyainya, karena yang demikian dianggap sebagai bentuk kepatuhan intelektual dan diyakini sebagai sesuatu yang terbaik untuk dirinya, baik di dunia ataupun kehidupan akhiratnya kelak.

Ada banyak kemungkinan hal yang melatarbelakangi praktik pernikahan di kalangan santri Jamaah Tabligh Pesantren Temboro, adakalanya faktor normatif, sosiologis, atau bahkan kultural. Titik inilah yang ingin dikaji dalam penelitian ini nantinya. Pertama, bagaimana konsep pemilihan jodoh yang dilakukan oleh santri putra atau wali santri Jamaah Tabligh di Pesantren Temboro? Kedua, bagimana praktik pernikahan yang dilakukan yang dilakukan oleh santri Jamaah Tabligh di Pesantren Temboro? Dan ketiga bagaimana "hak pilih" 
perempuan dalam penentuan jodoh yang dilakukan oleh wali atau bahkan pimpinan mereka?

\section{Metode Penelitian}

Kajian ini adalah kajian penelitian kualitatif dengan pendekatan normatif-sosiologis yakni upaya memahami fakta atau data lapangan dengan cara mengkonfirmasikannya dengan norma-norma atau dalil-dalil agama yang menjadi landasan sebuah praktik sosial. Lebih dari itu praktik keagamaan, dalam hal ini adalah perjodohan di kalangan santri Jamaah Tabligh, dicermati juga sebagai fakta yang tidak hanya didukung oleh norma agama, tetapi juga dilatarbelakangi oleh faktor sosialkeagamaan yang melingkupi.

Data dalam kajian ini dicari dengan tiga metode utama, yakni wawancara, observasi, dan dokumentasi. Pertama, beberapa pihak yang diwawancarai, yakni pengurus, santri yang telah menikah, dan pihak pengelola Pesantren Temboro ${ }^{4}$. Kedua, observasi dalam kajian ini diarahkan untuk mencermati kondisi Pesantren Temboro, proses pembelajaran, pola hubungan santri, dan juga kondisi masyarakat di sekitarnya. Hal ini penting dilakukan untuk melihat "setting kehidupan" Jamaah Tabligh di desa tersebut. Ketiga, mencermati dokumen atau data-data yang terekam dalam bentuk "hard file" ataupun "soft file" yang merekam berbagai aktivitas terkait.

Kajian ini akan berlangsung di Pesantren Temboro dengan beberapa pertimbangan. Pertama, Pesantren Temboro adalah salah satu pondok pesantren tua di Jawa Timur yang memiliki tradisi ahlus sunnah wal jamaah (nahdliyyin) yang telah bergeser secara "ideologis" menjadi gerakan Jamaah Tabligh. Kedua, di pesantren ini terdapat tradisi nikah di kalangan para santri yang difasilitasi oleh pihak pesantren.

4 Semua nama informan dalam penelitian ini disamarkan untuk menjaga kerahasiaan. 


\section{Pesantren Temboro dan Jamaah Tabligh}

Pesantren Temboro adalah sebuah pesantren tradisional (salaf) yang didirikan sebelum Indonesia merdeka oleh seorang kyai, yakni Kyai Shidiq ${ }^{5}$. Periode perintisan pesantren ini sebenarnya telah dimulai semenjak tahun 1939, ketika Kyai Shidiq mendirikan masjid yang kemudian diberi nama Al-Fatah pada 01 Mei 1939. Sebelumnya, masjid ini adalah sebuah mushola yang didirikan tahun 1930. Didirikannya masjid menggantikan mushola tidak lepas dari keinginan Kyai Shidiq untuk memberikan saran ibadah warga Temboro untuk melaksanakan ibadah.

Kyai Shidiq wafat pada usia 62 tahun pada tahun 1956. Pengasuhan Pesantren Al-Fatah kemudian beralih pada putranya Kyai Mahmud. Kyai Mahmud mulai bergerak secara serius membenahi pesantren yang ditinggalkan oleh ayahnya. Ia mulai mengatur manajemen pesantren layaknya pesantrenpesantren besar pada umumnya. Kyai Mahmud mulai menggerakan sistem pendidikan Pesantren Temboro dengan menambahkan sistem pembejalarannya. Lambat laun Pesantren Temboro mulai berkembang dengan baik.

Pesantren Temboro adalah pesantren salaf (tradisonal) sebagaimana pesantren lainnya yang beraliran ahlussunnah wal jamaah ala nahdliyin. Hanya saja yang membedakan dengan kebayakan pesantren lainnya adalah adopsi sistem dakwah ala Jamaah Tabligh semenjak akhir tahun 1980an. Kyai Mahmud sendiri adalah tokoh NU Kabupaten Magetan, serta pernah aktif sebagai Rais Syuriah PCNU Kabupaten Magetan tahun 19801984. Kyai Mahmud juga pernah aktif di kepengurusan partai

${ }^{5}$ Beberapa catatan Sejarah Pesantren Temboro ditulis oleh beberapa akademisi. Lihat Reza Ahmad Zahid, Studi Atas Strategi Dakwah Jamaah Tabligh di Desa Temboro, Magetan, (Yogyakarta: CRCS UGM, 2007) dan Farish A. Noor, The Spread of the Tablighi Jama'at... , dan lain-lain. 
politik NU sebelum akhirnya NU menarik diri dari panggung politik setelah muktamar NU di Situbondo tahun $1984 .{ }^{6}$

Kembalinya NU ke khittah jamiyyah dan tidak lagi berorientasi pada politik praktis ${ }^{7}$ membawa konsekuensi juga terhadap Kyai Mahmud dan pesantrennya. Kyai Mahmud nampaknya bertekad kuat untuk mengembankan pesantrennya menjadi rujukan dirasah Islamiyah yang kuat. Sehingga ia merintis banyak sistem pendidikan. Jamaah tariqah yang berkembang sejak awal, yakni taraiqat Naqsabandiyah juga terus berjalan sebagaimana biasa. Hanya saja orientasi gerakan dakwah mulai terasa di pesantren ini semenjak kedatangan rombongan Jamaah Tabligh dari Pakistan. ${ }^{8}$

Menurut Farish A Noor ${ }^{9}$ kedatangan Jamaah Tabligh di kawasan Magetan terjadi pada tahun 1984. Rombongan Jamaah Tabligh dari Pakistan ini adalah kafilah yang sedang melintasi kawasan Temboro, Kabupaten Magetan dari Surakarta menuju Surabaya. Sebagaimana proses awalnya masuknya Jamaah Tabligh ke Indonesia yang menggunakan koneksi hubungan sesama keturunan India atau Pakistan. Rombongan Jamaah Tabligh Pakitan ini juga menemui muslim keturunan India, Ustadz Fazaldin yang memiliki toko perhiasan di Magetan. Ustadz Fazaldin yang mengantarkan rombongan Tabligh yang dipimpin Prof Abdusobur Khan dari Pakistan bertemu dengan Kyai Uzairon.

Prof. Abdusobur adalah orang yang sangat bijak, memiliki pengetahuan luas dan taat menjalankan agama. Ia

\footnotetext{
${ }^{6}$ Reza Ahmad Zahid, Studi Atas Strategi Dakwah..., 266.

${ }^{7}$ Lihat catatan Andree Filliard mengenai khittah NU dan Politik praktis dalam NU vis-à-vis Negara: Pencarian Isi, Bentuk, dan Makna, (Yogyakarta: LKiS, 1999)

${ }^{8}$ Farish A. Noor, The Spread of the Tablighi ... , 39-43.

${ }^{9}$ Farish A. Noor, The Spread of the Tablighi ... , 39-43. lihat juga Farish A. Noor, Islam on the Move; The Tablighi Jama'at in Southeast Asia (Amsterdam: Amsterdam University, 2003), 46-48.
} 
berbicara dengan Kyai Uzairon, putra Kyai Mahmud dengan penuh kesopanan dan antutias yang tinggi tentang agama. Kyai Uzairon sangat terkesan dengan keilmuan, ketawadhuan serta religiusitasnya.

Prof. Abdusobur seolah ingin menggaet hati Kyai Mahmud melalui Kyai Uzairon sebagai putranya, sehingga mereka bisa menerima Jamaah Tabligh. Upaya ini berhasil dengan sukses karena Kyai Uzairon menerima Jamaah Tabligh sebagai sistem dakwah yang digunakan Pesantren Temboro. Bahkan Kyai Uzairon kemudian didaulat menjadi amir pertama, pimpinan tertinggi Jamaah Tabligh, untuk wilayah Jawa Timur pada tahun $1984^{10}$. Rentan tahun 1989 hingga 1993 banyak santri Temboro yang mulai dikirim ke India dan Pakistan untuk belajar ngaji di kedua negara tersebut. Alumni-alumni inilah yang kemudian sebagian besar kembali ke Pesantren Temboro dan khidmat mengajar santri.

Saat ini Pesantren Temboro bukanlah pesantren yang kecil dan biasa, namun telah memiliki ribuan santri. Rincian jumlah santri mukim sebanyak 10.450 orang, santri kalong artinya tinggal di sekitar pesantren karena rumahnya ada di sekitar pesantren sebanyak 1.935 orang, jumlah ustadz mencapai 810 orang, sehingga total jumlah 13.155 orang ${ }^{11}$. Belum lagi santri yang tersebar di cabang-cabang pesantren Temboro yang mencapai jumlah 6.409 santri yang berada di pesantren cabang Temboro ${ }^{12}$.

Pesantren Temboro kini memiliki tidak kurang 60 cabang yang ada di Indonesia tersebar di berbagai wilayah. Sehingga jumlah total seluruh santri Temboro baik yang tinggal di

${ }^{10}$ Farish A. Noor, The Spread of the Tablighi ... , 42.

${ }^{11}$ Data ini didapatkan dari blog santri, Cah Temboro, http://cahtemboro.blogspot.com/2016/12/santri-pesantren-al-fatahtemboro.html. Diakses 17 April 2017.

12 Wawancara dengan ustadz Jakfar, 17 Juli 2017. Semua nama informan dalam kajian ini disamakan untuk menutup data pribadi informan.

Ulul Albab: Jurnal Studi dan Penelitian Hukum Islam 
Jodoh dan Perjodohan Santri ... $\mid 31$

Temboro ataupun di pesantren cabang Temboro berjumlah kisaran 19.604 orang. Dari jumlah tersebut terdapat 646 santri yang berasal dari luar negeri ${ }^{13}$.

\section{Konsep Pemilihan Jodoh Santri}

Jodoh adalah hak Allah, manusia memiliki hak untuk memilih mana calon pasangan yang terbaik untuk dirinya dengan meminta petunjuk-Nya. Nampaknya ini bisa menjadi gambaran singkat yang cukup tepat untuk mendiskrispiskan bagaimana konsep pemilihan jodoh di kalangan santri Pesantren Temboro. Santri yang mengingikan menikah, karena memang usia mereka telah memasuki usia matang untuk menikah, akan mengutarakan niatannya dan pilihannya melalui doa-doa mereka dalam ibadah shalat.

Di sinilah santri-santri tersebut "membentuk dunia" mereka untuk menentukan pilihan atau preferensi berdasarkan keyakinan dogmatis agama. Ajaran dan ritual agama menjadi medium bagaimana preferensi tersebut ditentukan oleh kaum santri. Namun sebelum pilihan berdasarkan ritual agama ini dilakukan ada proses syariat yang mengiringi. Proses ini adalah proses lahiriah yang dapat ditempuh oleh santri sebelum mengkomunikasikan pilihan tersebut pada Allah, Tuhan penguasa alam.

Beberapa bagian yang harus diperhatikan adalah kesederajatan pasangan (kafa'ah). Konsep ini merujuk hadits Rasulullah tentang kesederajatan (kafaah); harta, keturunan, kecantikan, dan agama ${ }^{14}$. Kafaah merupakan ukuran paling konkrit mengukur keharmonisan yang akan dijalani pasangan

13 Lihat blog Cah Temboro

http://cahtemboro.blogspot.com/2016/12/santri-pesantren-al-fatah-

temboro.html. Diakses 17 April 2017.

${ }^{14}$ Imam Muslim, Shahih Muslim Juz 2, (Beirut: Dar Ihya' Turats Arabi), 1086. lihat Sayyid Sabid, Fikih Sunah, Bandung: Al-Ma'arif, 1997, 
tersebut. ${ }^{15}$ Hampir seluruh ulama madzhab menyekapati perlunya kafaah dalam pernikahan, namun mereka berselisih dalam beberapa persoalan. Kesepatakan para ulama terutama terletak pada persoalan agama, Islam, merdeka, dan keturunan ${ }^{16}$.

Nampaknya inilah yang menjadi pegangan santri Pesantren Temboro yakni agama atau pekerti masing-masing calon mempelai. Sehingga mereka menekankan pentingnya memperhatikan karakter (ikhwal) masing-masing calon. Hal ini sebagaimana diungkapkan Ustadz Rony yang menjadi biro penghubung atau biro jodoh di Pesantren Temboro.

"Saya akan menyampaikan ihwal perempuan kepada lakilaki yang meminta istri dan ikhwal laki-laki kepada pihak perempuan. Bahwa orang ini sudah mondok sekian tahun, ngajinya bagus, sudah hafal Al-Qur'an 30 juz, 15 juz atau 5 juz saja. Ini menjadi modal bagi masing-masing calon untuk melanjutkan ke proses berikutnya".${ }^{17}$

Mengenai kondisi kedua orang tua juga disampaikan oleh Ustadz Roni, namun sekali lagi hal yang paling penting dalam ukuran kafaah terkait dengan orang tua adalah agamanya. Karena sebagian besar santri Pesantren Temboro keluarga Jamaah Tabligh maka hal-hal yang disampaikan juga terkait dengan ikhwal kedua orang tua masing-masing calon ${ }^{18}$.

Hal ini menunjukkan bahwa kadar kesamaan pemahaman agama dan pekerti yang terkait dengan perilaku

15 Abd. Rahman Ghazaly, Fikih Munakahat (Jakarta: Prenada Media, 2003), 96.

${ }^{16}$ Lihat beberapa pembahasan dalam hal ini pada karya-karya berikut, seperti Ibnu Rusyd, Bidayatul Mutjahid wa Nihayatul Muqtasid (terjemahan oleh Mad'ali), (Bandung: Trigenda Karya, 1996); Muhammad Jawad Mughniyah, Figh Al-Imam Ja'far Ash-Shadiq Ardh wal Istidal (Juz 5 dan 6), (Jakarta: Lentera, 2009); Ibrahim Muhammad Al-Jamal, Fiqih Wanita (Semarang: Cv Asy-syifa, 1986); Sayyid Sabid, Fikih Sunah (Bandung: Al-Ma'arif, 1997); dan lain-lain.

17 Wawancara dengan Ustadz Roni di Temboro, 16 Oktober 2017.

${ }^{18}$ Wawancara dengan Ustadz Roni di Temboro, 16 Oktober 2017. 
agama menjadi syarat yang seolah tidak dapat ditolak atau paling tidak pertimbangan penting dalam menentukan pilihan. Meskipun harta dan keberadaan kelapangan hidup yang dimiliki oleh masing-masing orang tua kadang tidak menjadi pertimbangan yang pasti. Beberapa ustadz memberikan gambaran mengenai hal ini ada banyak santri dari kalangan keluarga yang secara ekonomi rendah menikah dengan santri dari kalangan berada.

Ustadz Roni menggambarkan kadang ada yang meminta dicarikan istri. Berdasarkan beberapa pertimbangan Ustadz Roni memilihkan santri khidmatan, yakni santri yang mengabdikan diri dari ke pesantren sebagai juru masak atau bersih-bersih. Namun keduanya juga merasa cocok dan akhirnya berlanjut hingga proses ke jenjang pernikahan. Namun Ustadz Roni menginformasikan juga kadang santri khidmatan tidak mesti dari keluarga miskin ${ }^{19}$. Sehingga konsep pemilihan jodoh bagi santri Pesantren Temboro tidak murni didasarkan pada kepemilikan harta dan keberadaan orang tua masingmasing calon. Sebagian besar didasarkan pada pilihan karena ketaatan dan pengetahuan agama yang dimiliki.

\section{Proses Pemilihan Jodoh}

Ada beberapa proses bagaimana jodoh ditentukan oleh santri Temboro. Hal ini nampaknya tergantung pada situasi yang melingkupi masing-masing pasangan yang akan memasuki jenjang pernikahan. Artinya bagaimana pasanganpasangan yang menemukan jodoh menentukan proses pemilihan tersebut dilakukan. Namun secara general proses pemilihan tersebut dapat digambarkan sebagaimana uraian di bawah ini.

${ }^{19}$ Wawancara dengan Ustadz Jakfar, 16 Juli 2019. 
1) Memanfaatkan Biro Jodoh Pesantren

Pesantren Temboro memiliki biro jodoh tersendiri meskipun tidak ada papan nama atau iklan yang digunakan untuk mensosialisasikan keberadaannya. Namun di kalangan santri baik putra ataupun putri mereka mengetahui keberadaan biro jodoh yang ada di pesantren tersebut. Biro jodoh ini dimanfaatkan santri untuk menjadi pintu yang mampu mengenalkan santri dengan calon pasangan yang diinginkan.

Biro jodoh ini dipegang oleh ustadz senior yang tinggal di dalam pesantren tersebut. Ustadz inilah yang memediasi "hubungan" santri putra dan putri yang telah menginginkan akan menikah namun belum memiliki calon pasangan. Ada beberapa model bagaimana santri meminta dicarikan calon pasangan hidupnya. Pertama, ada santri putra yang meminta secara langsung pada ustadz tersebut untuk dicarikan pasangan dengan menyebut ciri atau karakter (ikhwal) calon pasangan yang ia inginkan. Kedua, ada orang tua santri putri yang pasrah kepada ustadz tersebut untuk dicarikan pasangan bagi putrinya karena memang usia putrinya telah memasuki usia pernikahan dan proses belajarnya hampir usai ${ }^{20}$.

Biro jodoh ini memiliki tugas mencarikan calon pasangan santri putra yang telah menginginkan memiliki istri. Biro akan memilah-milah santri-santri putri yang telah cukup matang secara usia dan keilmuan untuk diberikan informasinya pada santri putra yang meminta tersebut. Jika alternatif pilihan sudah ada, biro akan memanggil santri putra yang meminta tersebut untuk diberi informasi mengenai ikhwal (karakter dan ciri-ciri) santri putri yang siap dinikahi. Informasi $i k h w a l$ santri putri tersebut biasanya disampaikan seputar mengenai daerah asal, lama tinggal di

${ }^{20}$ Wawancara dengan Ustadz Roni di Temboro, 16 Oktober 2017. 
pesantren, pengetahuan yang ia miliki, seperti telah hafal Al-Qur'an secara keseluruhan (30 juz) atau masih sebagian saja, orang tua santri putri tersebut, dan lain-lain.

Tidak jarang pula santri putra yang minta dicarikan jodoh tersebut meminta foto santri putri yang dimaksud. Ada sebagian santri putri yang bersedia memberikan fotonya, ada pula yang menolak memberikan foto. Foto yang diberikan hanya memberikan gambar wajah karena bagian yang lain tertutup baju dan hijab yang mereka kenakan. Namun sebagian ada pula yang menolak memberikan foto karena beberapa alasan.

Menurut penuturan Ustadz Ghulam, santri yang menolak memberikan foto karena ada trauma tertentu, seperti ia pernah dikenalkan dengan santri putra kemudian sampai pada tahap nadhar (bertemu untuk melihat wajah) namun gagal melanjutkan ke jenjang pernikahan. Sehingga ia khawatir jika memberikan foto nanti hanya akan ditolak dan menjadi aib bagi dirinya ke depan ${ }^{21}$.

Setelah biro memberikan informasi mengenai ikhwal santri putri yang ditawarkan kepada santri putra yang meminta dicarikan istri tersebut, biro meminta santri putra tersebut untuk shalat istikharah. Shalat istikharah ini dimaksudkan untuk meminta pentunjuk langsung dari Allah mengenai cocok tidaknya calon yang telah dikenalkan sang ustadz. Demikian pula terhadap santri putri yang telah "diprospek" untuk menjadi istri dari santri putra yang meminta, santri putri ini diminta untuk shalat istikharah. Hal ini dimaksudkan untuk meminta pada Allah apakah masing-masing calon tersebut memang jodoh yang telah ditentukan.

Biro jodoh memiliki kewajiban untuk memfasilitasi masing-masing santri putra dan putri untuk menemukan

${ }^{21}$ Wawancara dengan Ustadz Roni di Temboro, 16 Oktober 2017 
jodoh. Biro hanya mengenali karakter atau ikhwal yang dimiliki masing-masing calon pasangan. Namun ia tidak mengenali wajah dari santri putri tersebut, karena biro jodoh ini seorang laki-laki. Mengenai sifat fisik biro mengaku tidak memilik hak untuk melihatnya. Melihat foto dan proses nadhar nanti yang akan menentukan masingmasing calon menentukan lanjut proses tersebut atau berhenti ${ }^{22}$.

Biro hanya menjadi penghubung hingga kedua calon menemukan kata mufakaat. Proses selebihnya jika akan berlangsung pernikahan diserahkan pada bagian tersendiri, yakni "menteri pernikahan" atau ustadz yang bertugas memberikan arahan prosesi pernikahan yang dilangsungkan di pondok.

2) Mengenal calon pasangan sebelum mondok

Tidak sedikit dari santri yang berangkat ke pondok dari tempat asal yang sama atau bahkan alumni sekolah yang sama saat mereka masih duduk di bangku MI/SD atau MTs/SMP. Bahkan dimungkinkan mereka pernah memendam rasa cinta saat masih duduk di bangku MTs/SMP. Sehingga tidak jarang mereka yang menyimpan rasa itu hingga mereka mampu menuntaskan pendidikan di Pesantren Temboro.

Mereka yang sudah saling kenal sebelum mondok di Pesantren Temboro memiliki peluang untuk menjadi hubungan ke jenjang perkawinan jika selama mereka mondok tidak menemukan jodoh. Bahkan dimungkinkan mereka bisa menjalin hubungan komunikasi satu dengan lainnya dengan cara-cara yang mereka rahasiakan ${ }^{23}$.

Proses perkenalan sebelum mereka mondok di Pesantren Temboro bukan berarti negatif, tetapi tidak

\footnotetext{
${ }^{22}$ Wawancara dengan Ustadz Roni di Temboro, 16 Oktober 2017

${ }^{23}$ Wawancara dengan Ustadz Ghulam di Temboro tanggal 17 Oktober 2017.
}

Ulul Albab: Jurnal Studi dan Penelitian Hukum Islam 
sedikit pula yang memiliki makna positif. Sebagaimana pengamalan salah seorang ustadz yang telah mengenal istrinya ketika masih kecil.

3) Perjodohan antar orang tua

Perjodohan yang dilakukan oleh orang tua terhadap anak-anaknya bukanlah hal yang baru bagi masyarakat santri. Maklum santri tidak memiliki kemungkinan bertemu secara intens dengan lawan jenisnya. Sementara orang tua mereka memiliki cara tersendiri dalam menjodohkan anak-anaknya. Salah satunya dengan cara menjodohkan mereka dengan anak-anak sahabatnya. Terlebih jika masing-masing orang tua merupakan alumni pesantren yang sama. Kadang terdapat sebuah kebanggaan bagi orang tua jika dapat menikahkan anak-anaknya dengan anak sahabatnya, karena hal demikian seperti menghidupkan persahabatan lama.

Nampaknya hal ini juga terjadi bagi sebagian orang tua santri Pesantren Temboro. Dimungkinkan orang tua santri juga merupakan alumni Pesantren Temboro sehingga mereka menikahkan anak-anak mereka karena adanya ikatan emosional tersendiri bagi orang tua. Selain itu pertemuan ketika mereka berkunjung ke Pesantren Temboro untuk menjenguk anak-anak mereka menjadikan alasan tersendiri bagi orang tua untuk menjalin hubungan lebih jauh sebagai besanan (mertua).

Kesamaan pola fikir dan tujuan yang sama dalam dakwah fi sabilillah dalam Jamaah Tabligh juga menjadi alasan kuat mereka menikahkan anak-anak mereka. Dalam hal ini tentu bukan saja ketika mereka berkunjung ke Pesantren Temboro mereka memiliki waktu bertemu, tetapi juga saat mereka khuruj di berbagai tempat. Ustadz Ghulam menuturkan bahwa hal yang sangat lumrah terjadi di kalangan santri Temboro menikah karena keinginan orang 
tua menjodohkan mereka dengan putra atau putri sahabatnya.

4) Shalat Istikharah

Shalat istikharah adalah proses yang hampir tidak dapat dilepaskan dari prosesi pemilihan jodoh santri Pesantren Temboro. Jika mereka telah meminta dicarikan jodoh, akan dinikahkan atau dijodohkan hal yang tidak boleh ditinggalkan adalah shalat istikharah untuk meminta pentunjuk Allah akan kebaikan dirinya ke depan jika menerima calon pasangan.

Atas dasar pertimbangan tersebut para santri Temboro yang telah membulatkan niat untuk mulai membangun rumah tangga selalu memasrahkan urusannya jodohnya dengan cara istikharah. Hal ini dilakukan karena ia tidak memiliki kesempatan untuk mengenal lebih jauh selain ikhwal atau karakter yang disampaikan oleh biro jodoh, orang tua, atau kyai mereka.

Santri memasrahkan urusan kebaikan calon jodohnya kepada Allah karena sulit bagi mereka untuk mengenal lebih dalam selain hal-hal yang bersifat dzahir. Hal ini sebagaimana diungkapkan oleh ustadz Ghulam.

"Jika saya sudah menemukan pilihan bagi yang meminta dicarikan jodoh, saya akan mengundang yang meminta. Kemudian menyampaikan informasi ikhwal perempuan. Saya lantas meminta yang bersangkutan untuk istikharah. Jika ia memiliki kemantapan hati mereka akan bilang ke saya "saya sudah mantab dengan pilihan tersebut" atau sebaliknya "tidak dulu". Demikian yang putri juga saya minta hal yang sama untuk melakukan shalat istikharah" ${ }^{24}$

${ }^{24}$ Wawancara dengan Ustadz Ghulam di Temboro tanggal 17 Oktober 2017. Hal ini juga dibenarkan oleh ustadz Abdullah yang menuturkan pengalaman dirinya. Wawancara 16 Juli 2017.

Ulul Albab: Jurnal Studi dan Penelitian Hukum Islam 
5) Nadhar, pertemuan untuk melihat

Proses selanjutnya setelah memantapkan pilihan dengan shalat istikharah, santri yang bersangkutan akan melangsungkan nadhar (melihat). Proses ini tepat sebagaimana bahasa tersebut, yakni bertemu untuk melihat wajah calon istrinya. ${ }^{25}$ Maksud melihat dalam proses menuju pertunangan adalah untuk memastikan bahwa ia merasa cocok dengan calon pasangan. Proses nadhar dalam fiqh dimaknai sebagai proses menuju khitbah, karena nadhar terhadap perempuan hanya boleh dilakukan jika ia betulbetul berniat untuk menikahi perempuan tersebut.

Hal ini sebagaimana dijelaskan dalam sebuah hadits yang diriwayatan oleh Abu Daud dari Jabir yang menyatakan "apabila salah seorang di antara kamu meminang seorang perempuan, dan merasa harus dapat melihat hal yang menarik untuk mengawininya, boleh ia lakukan". ${ }^{26}$ Turmudzi juga meriwayatkan, ketika Mughirah bin Syu'bah meminang seorang perempuan, sampai bertanya kepada Rasulullah SAW. Kemudian Rasulullah menanyakan kepada Mughirah apakah pernah melihat perempuan yang dipinang itu. Mughirah mengatakan bahwa ia belum pernah melihatnya. Kemudian Rasulullah bersabda "lihatlah dulu perempuan itu sebab melihat perempuan yang akan dipinang itu lebih menjamin kelangsungan perkawinan kalian berdua" ${ }^{27}$

Karena itu para ulama menyimpulkan bahwa nadhar atau melihat perempuan yang akan dipinang boleh dilakukan dalam dua kondisi. Pertama, pihak laki-laki harus

${ }^{25}$ Lihat Ibnu Rusyd, Bidayatul Mutjahid ... , 354.

${ }^{26}$ Abu Daud, Sunan Abi Daud Juz 2, Beirut: Maktabah Al Ashriyah, 228

${ }^{27}$ Lihat hadits Riwayat at Turmudzi, Imam At Turmudzi, Sunan At

Tirmidzi Juz 3, (Mesir: Maktabah Mustafa al Halabi, tt) 389. lihat juga pada Sayyid Sabid, Fikih Sunah. 
benar-benar memiliki niat untuk menikahinya ${ }^{28}$. Kedua, ada peluang untuk menikahinya, seperti, memungkinkan untuk diizinkan walinya, atau memungkinkkan untuk diterima pihak perempuan. Jika kemungkinan besar pasti ditolak, baik oleh pihak wali atau perempuan yang dinadhar maka tidak boleh tetap nekad untuk nadhar. Hal ini sebagaimana disampiakan Ibnul Qatthan Al-Fasi ${ }^{29}$ dalam Ahkam AnNadhar mengatakan "Jika lelaki yang hendak meminang perempuan mengetahui bahwa pihak perempuan tidak akan bersedia nikah dengannya, atau pihak wali tidak akan mengabulkan pinanganya, maka tidak boleh dia melakukan nadhar. Meskipun dia sudah menyampaikan lamarannya. Karena dibolehkannya nadhar, hanya karena menjadi sebab untuk menikah. Jika dia yakin bahwa dia pasti ditolak, maka kembali pada hukum asal melihat perempuan, yaitu dilarang.

Dalam tradisi nadhar yang dilakukan santri Temboro, prosesi nadhar bisa dibilang 80 persen pernikahan itu akan terjadi. Artinya prosesi nadhar memang untuk memantapkan hati masing-masing pihak untuk melangkah pada proses selanjutnya. Sehingga nadhar bukan hanya sebatas "main-main" mata antara santri laki-laki dan perempuan.

Ustadz Roni ${ }^{30}$ menyatakan "boleh dikata jika nadhar dilakukan itu 80 persen kedua santri akan melakukan prosesi selanjutnya yakni khitbah atau pertunangan. Meskipun ada juga yang hingga sampai nadhar kemudian tidak terjadi pertunangan ataupun pernikahan tetapi sangat

${ }^{28}$ Ahmad Ibn Hanbal, Musnad Ahmad, Beirut: Muassasah Ar Risalah, 2001), 15.

29 Ibn Al-Qattan al-Fasi's, "Ahkam al-Nazar bi-Hassat al-Basar" in: Islamic Law and Society, Vol. 14, No. 3. (2007), 391.

${ }^{30}$ Wawancara tanggal 16 November 2017.

Ulul Albab: Jurnal Studi dan Penelitian Hukum Islam 
\begin{tabular}{l|l} 
Jodoh dan Perjodohan Santri ... & 41
\end{tabular}

jarang karena jika tidak akan terjadi pernikahan pasti berhenti pada proses pemantapan dalam istikharah".

\section{Khitbah dan Konsep Pernikahan}

Sebagaimana proses pernikahan pada umumnya dalam kajian fikih, setelah semua hal di atas dilalui maka kedua belah pihak akan melangsungkan pertunangan (khitbah)31. Secara umum khitbah yang dilakukan oleh santri Temboro dapat dilihat dalam tiga model. Pertama, masing-masing keluarga saling berkunjung. Khitbah dilakukan di rumah calon pengantin perempuan dengan cara keluarga laki-laki mengutarakan maksud dan tujuan kedatangan hingga pertunangan. Penentuan hari pernikahan kadang juga dilakukan, namun biasanya banyak dibuat kesepatakan karena pernikahan akan dilangsungkan di Pesantren Temboro.

Kedua, jika masing-masing rumah asal calon mempelai jauh, masing-masing keluarga datang ke Temboro untuk melakukan pertunangan. Salah satu keluarga menyewa rumah penduduk di Temboro untuk waktu satu atau dua hari untuk keperluan pertunangan. Ketiga, pertunangan hanya dilakukan via telefon. Hal ini karena keluarga dipisahkan jarak yang cukup jauh.

Proses selanjutnya adalah mengurus administrasi pernikahan. Sebagian besar santri Temboro akan melangsungkan pernihakan di Pesantren Temboro. Santri yang akan menikah melapor terlebih dahulu kepada "menteri urusan nikah".

Beberapa persiapan tersebut dapat berupa persiapan administratif dan persiapan teknis lapangan. Persiapan administrasi adalah kelengkapan surat-surat pernikahan yang harus disipakan kedua mempelai. Selain administrasi

31 Lihat Abd. Rahman Ghazaly, Fikih Munakahat, (Jakarta: Prenada Media, 2003), 74. 
pemerintah adalah kesiapan lapangan, mulai dari mahar, tata rias, dan jamuan makan untuk tamu.

Bagi santri Temboro prinsip dalam pernikahan adalah "menikah sesederhana mungkin, mahar sebanyak yang dimampu". Santri Temboro akan memberikan mahar sebaik dan sebanyak yang mereka mampu. Tradisi yang berkembang dalam pernikahan santri Temboro memberikan mahar pada calon istrinya dengan uang dalam jumlah yang cukup banyak. kisarannya antara Rp. 3.000.000 hingga Rp. 30.000.000. hal ini tergantung pada kemampuan santri yang bersangkutan ${ }^{32}$.

Ada pula pemberian mahar berupa uang Dinar ataupun Dirham. Besaran uang Dinar dan Dirham juga tergantung pada kemampuan masing-masing mempelai putra. Uang Dinar dan Dirham adalah mata uang Saudi Arabia yang dibuat dari logam mulia, Dinar dari emas dan Dirham dari Perak. Besaran masingmasing mata uang tersebut tentu saja berbeda ${ }^{33}$.

Sementara untuk persiapan teknis lain berupa jamuan makan dan rias pengantin. Jamuan makan untuk tamu undangan seperti layaknya pesta pernikahan lainnya. Jamuan makan disesuaikan dengan jumlah tamu yang diundang dalam walimah (pesta pernikahan) tersebut. Jamuan makan akan ditanggung bersama kedua mempelai atau satu pihak mempelai saja. Hal ini sesuai kesepakatan kedua belah pihak mempelai. Hanya saja pernikahan santri Temboro bersifat massal sehingga jamuan makan ditanggung bersama menyesuaikan jumlah tamu yang diundang masing-masing mempelai.

Selain jamuan untuk tamu, ada pula jamuan makan khusus kyai dan keluarga. Jamuan ini bersifat spesial mengingat kyai adalah orang tua santri dalam ilmu agama dan panutan dalam keagamaan. Jamuan untuk kyai ditanggung secara

${ }^{32}$ Beberapa Ustadz yang telah menikah di Pesantren menyatakan hal ini bahkan menyebutkan contoh kasus dirinya, seperti Ustadz Roni, Ghulam, Jakfar, Zaid, Abdullah dan lain-lain.

${ }^{33}$ Wawancara dengan Ustadz Ghulam, 17 November 2017. 
bersama dalam rombongan nikah pada saat itu ${ }^{34}$. Pernikahan dilaksanakan di rumah kyai pada aula besar yang telah disiapkan. Pernikahan santri dilaksanakan pada hari Kamis siang setelah Dzuhur atau pukul 13.00 hingga pukul 15.00 atau tergantung jumlah pasangan yang menikah.

Nampaknya di sinilah sisi sederhana pesta pernikahan tersebut karena tidak memerlukan waktu dan biaya yang mahal karena harus berhari-hari menyiapkan perlengkapan menikah dan pesta pernikahan. Jamuan untuk tamu dan kyai bisa dipesan tanpa harus melibatkan banyak orang dalam persiapannya. Tata rias pengantin juga tidak perlu mengudang dari luar karena telah disiapkan pihak pesantren.

\section{Hak Pilih Perempuan dalam Jodoh}

Laki-laki dan perempuan memiliki hak yang sama dalam persoalan memilih pasangan ${ }^{35}$. Hanya saja keduanya dibedakan, jika laki-laki-laki menawar, maka perempuan memiliki hak untuk memilih atau menolak ${ }^{36}$. Perbedaan ini dikarenakan persoalan sosiologis kultral yang melingkupi munculnya hak pilih baik laki-laki ataupun perempuan dalam budaya patriarkhis.

Demikian halnya dalam Islam memberikan hak yang sama dalam persoalan memilih jodoh baik laki-laki ataupun perempuan. Islam mendudukan sejarah hak pilih laki-laki dan perempuan dalam masalah jodoh. Hanya mungkin terdapat satu kebolehan "pemaksaan" jodoh yang dilakukan oleh orang tua

${ }^{34}$ Wawancara dengan Ustadz Ghulam, 17 November 2017.

35 Kyai Husein Muhammad menawarkan keadilan dalam persoalan gender, lihat Husein Muhammad, Figh Perempuan, Reflksi Kiai atas Wacana Agama dan Gender, LKiS: Yogyakarta, 2001. Lihat pula Zaitunah Subhan, Tafsir Kebencian: Studi Bias Gender dalam Tafsir Al-Qur'an, Yogyakarta: LkiS, 1999.

36 Lihat Muzadi, Abd. Muchith, Fiqih Perempuan Praktis, Khalista: Surabaya, 2006 dan Ibrahim Muhammad Al-Jamal, Fiqih Wanita, Semarang: Cv Asy-syifa, 1986. 
atau wali terhadap anak-anak perempuan mereka. Hal inilah yang kemudian dikenal dengan hak ijbar atau kuasa wali untuk menikahkan anak perempuan yang ia miliki.

Hanya saja hak tersebut juga dibatasi, yakni tidak boleh adanya pemaksaan terhadap anak perempuan jika tidak menyukai laki-laki yang ditawarkan walinya. Hal ini sesuai dengan tuntutan Rasulullah yang meminta orang tua atau wali memaksakan kehendaknya pada anak perempuan mereka untuk menikah dengan laki-laki pilihan walinya ${ }^{37}$.

Hadits-hadits Nabi Muhammad SAW yang berisi tentang hal ini, menegaskan hak perempuan dalam memilih, sebagaimana sabdanya, "Seorang janda tidak boleh dinikahkan sebelum berunding dengannya, dan seorang perawan tidak boleh dinikahkan sebelum mendapatkan persetujuannya". Orang-orang lalu bertanya, "Wahai Rasulullah, bagaimana cara dia memberi persetujuan?". Beliau menjawab, "Dengan diamnya".

Nilai-nilai ini pula yang nampaknya diimplementasikan oleh santri Temboro dalam pemilihan jodoh. Santri putri memang memiliki kecenderungan pasif dalam memilih, namun ia memiliki hak untuk menyatakan menerima atau menolak lakilaki yang berniat pada dirinya. Sangat jarang kasus santri putri meminta dicarikan secara langsung, namun kesiapan santri putri menerima pinangan dari pihak laki-laki melalui biro jodoh Pesantren Temboro menunjukkan perempuan memiliki kuasa akan dirinya untuk menentukan jodoh atau paling tidak kapan ia harus menikah atau masih membujang.

Dalam konteks wali mujbir, memang terjadi dalam kehidupan santri Temboro. Namun sejauh temuan penelitian ini semuanya masih dalam konteks yang wajar, artinya tidak ada paksaan dalam perjodohan. Semuanya berjalan dalam koridor

${ }^{37}$ Lihat Abu Bakar, Kawin Paksa: Problem Kewenangan Wali dan Hak Perempuan dalam Menentukan Jodoh, Jurnal Al-Hakam, vol. V, No. 1 Juni 2010, 81-98.

Ulul Albab: Jurnal Studi dan Penelitian Hukum Islam 
syariat sebagaimana diyakini masyarakat santri Temboro. Sifat dan karakter yang dibentuk dalam pengetahuan santri Temboro nampaknya juga memberikan pengaruh pada kesadaran yang dimiliki santri putra ataupun putri Temboro. Misalnya kesadaran harus mengikuti perintah orang tua, orang tua adalah panutan yang tidak mungkin menyesatkan putranya, kesadaran syariat dan ketentuan agama, dan lain sebagainya.

Biro jodoh tidak dapat disamakan dengan wali mujbir karena sifatnya hanya memberikan perantara dan informasi mengenai calon pasangan yang ingin mempersunting. Demikian halnya kyai dalam konteks tertentu tidak sama dengan wali mujbir meskipun bisa meminta santri putri untuk menikah dengan laki-laki tertentu. Bahkan tidak jarang orang tua wali yang pasrah pada kyai untuk mencarikan calon suami bagi putrinya. Namun semuanya berjalan sesuai dengan keinginan pihak perempuan. Artinya kyai tidak memiliki daya paksa dan hanya penawaran. Penawaran berdasarkan cara pandang terbaik untuk anak-anaknya layaknya orang tua atau wali sendiri. ${ }^{38}$

Hak pilih perempuan dalam konteks masyarakat santri sebagaimana di Pesantren Temboro dapat dipahami sebagai bentuk dialektif kesederajatan sebagaimana syariat agama yang mereka pahami. Pemahaman norma agama memberikan bentuk kesadaran yang mereka miliki dan kemudian menjadi tradisi dalam kehidupan sosial masyarakat santri. ${ }^{39}$

\section{Kesimpulan}

Tradisi pemilihan jodoh, perjodohan, dan pernikahan di kalangan santri Temboro merupakan bentuk kesadaran

${ }^{38}$ Wawancara dengan Ustadz Roni di Temboro tanggal 18 November 2017.

${ }^{39}$ Lihat Sukron Ma'mun, “Konsep Keluarga Dan Perempuan Dalam Perspektif Jamaah Tabligh: Analisa Normatif-Sosiologis", MISKAT: Jurnal IlmuIlmu Al-Qur'an, Hadits, Syariah dan Tarbiyah, Vol 4, No 1 (2019). 55-78. 
pengetahuan agama mengenai salah satu sisi kehidupan sosial santri. Pengetahuan agama mengenai pernikahan kemudian merembes dalam tradisi pernikahan santri menjadi potret menarik yang dapat dicermati dalam bahasan di atas. Beberapa hal yang mungkin dapat dipetik dalam kajian tersebut dapat penulis bagi dalam dua wilayah, sosiologis dan hukum Islam. Secara sosiologis, pertama, keterbatasan akan kontak secara fisik ataupun interaksi secara langsung membawa kesadaran keagamaan santri untuk melakukan sebuah ritual logis spiritual, bagaimana mereka menyakini jodoh dalam ritual shalat istikharah.

Kedua, proses-proses perjodohan memberikan sebuah diskusi yang cukup menarik bagaimana proses sosial berlangsung dalam tradisi pemilihan jodoh. Dipilihkan orang yang orotitatif, dipilihkan orang tua, atas keyakinan pribadi, pilihan lama, dan lain sebagainya. Proses interaksi memalui nadhar secara sosiologis juga menarik untuk dicermati. Di sinilah kesadaran pengetahuan agama dan tradisi budaya dilestarikan oleh masyarakat santri yang menjunjung tinggi keyakinan tradisi agama. Ketiga, hak pilih perempuan dalam jodoh menjadi gambaran mengenai bagaimana masyarakat santri tetap melestrarikan budaya atau kultur patriarkhis, namun akomodatif terhadap perubahan. Hal ini juga memberikan sebuah gambaran bahwa masyarakat santri tetap setia pada teks agama.

\section{Daftar Pustaka}

At Turmudzi. Sunan At Tirmidzi Juz 3. Mesir: Maktabah Mustafa al Halabi

Al-Fasi's, Ibn Al-Qattan. 2007. “Ahkam al-Nazar bi-Hassat alBasar" in: Islamic Law and Society, Vol. 14, No. 3.

Ali, Jan A. 2010. “Tabligh Jama' at: A Transnational Movement of Islamic Faith Regeneration", Jurnal Ejeps, Vol. 2. 
\begin{tabular}{l|l} 
Jodoh dan Perjodohan Santri ... & 47
\end{tabular}

Al-Jamal,Ibrahim Muhammad. 1986. Fiqih Wanita, Semarang: CV Asy-syifa.

Al-Kutub Al-Muqorroroh Program Pondok Pesantren Al-Fatah. 2016. Temboro. Karas Magetan. Jawa Timur.

Aziz, Abdul. 2004. “The Jamaah Tabligh Movement in Indonesia: Peaceful Fundamentalist", Jurnal Studia Islamika, Vol. 11, No. 3.

Bakar, Abu. 2010. Kawin Paksa: Problem Kewenangan Wali dan Hak Perempuan dalam Menentukan Jodoh, Jurnal AlHakam, vol. V, No. 1 Juni.

Dhofier, Zamakhsari. 1999. Tradisi Pesantren: Studi Pandangan Hidup Kyai, Jakarta: LP3ES.

Feillard, Andree. 1999. NU vis-à-vis Negara: Pencarian Isi, Bentuk, dan Makna, Yogyakarta: LKiS.

Ghazaly, Abd. Rahman. 2003. Fikih Munakahat, Jakarta: Prenada Media.

Ibn Hanbal, Ahmad. 2001. Musnad Ahmad. Beirut: Muassasah Ar Risalah.

Ma'mun, Sukron. 2013. Arabic-Islamic Culture of Tablighi Jamaat: A Case Study in Hyderabad, Indian (penelitian), Hyderabad, EFLU Hyderabad, India.

"Konsep Keluarga Dan Perempuan Dalam Perspektif Jamaah Tabligh: Analisa Normatif-Sosiologis", MISKAT: Jurnal Ilmu-Ilmu Al-Qur'an, Hadits, Syariah dan Tarbiyah, Vol 4, No 1 (2019)

Muhammad, Husein. 2001. Figh Perempuan, Reflksi Kiai atas Wacana Agama dan Gender, LKiS: Yogyakarta.

Muslim. Shahih Muslim Juz 2. Beirut: Dar Ihya' Turats Arabi

Muzadi, Abd. Muchith. 2006. Fiqih Perempuan Praktis, Khalista: Surabaya.

Noor, Farish A. 2003. Islam on the Move; The Tablighi Jama'at in Southeast Asia, Amsterdam: Amsterdam University. . 2009. The Spread of the Tablighi Jama'at Across Western, Ventral, and Eastern Java and the Role of India Muslim 
Diaspora (RSIS Working Paper, No. 175), Singapore: Nanyang Technological University.

Rusyd, Ibnu. 1996. Bidayatul Mutjahid wa Nihayatul Muqtasid (terjemahan oleh Mad'ali), Bandung: Trigenda Karya.

Sabid, Sayyid. 1997. Fikih Sunah, Bandung: Al-Ma'arif.

Subhan, Zaitunah. 1999. Tafsir Kebencian: Studi Bias Gender dalam Tafsir Al-Qur'an, Yogyakarta: LkiS.

Temboro, Cah. 2014. Kurikulum PP. Al-Fatah Tahun 2014 pada http://cahtemboro.blogspot.co.id/2016/01/kurikulum-

pondok-pesantren-al-fatah-2014_2.html, akses 17 April 2017.

Zahid, Reza Ahmad. 2007. "Studi Atas Strategi Dakwah Jamaah Tabligh di Desa Temboro, Magetan" Yogyakarta, CRCS UGM.

\section{Daftar Wawancara}

Wawancara dengan Ustadz Jakfar 15 dan 16 Juli 2017.

Wawancara dengan Ustadz Abdullah 16 Juli 2017.

Wawancara dengan Ustadz Zaid 16, 17 Oktober 2017.

Wawancara dengan Ustadz Roni, 16, 18 November 2017.

Wawancara dengan ustadz Ghulam 17, 18 November 2017. 